\title{
Capillary leakage with inflammation and surgery
}

\author{
A Komáromi ${ }^{1}$, U Estenberg ${ }^{2}$, J Wernerman ${ }^{1,3}$, O Rooyackers ${ }^{3}, \AA$ Norberg ${ }^{1,3^{*}}$ \\ From ESICM LIVES 2015 \\ Berlin, Germany. 3-7 October 2015
}

\section{Introduction}

The patency of the capillary wall is compromised in inflammation, stress, and fluid overload resulting in extravasation of water and macromolecules [1]. Reliable measurement of capillary leakage is an important tool in the pursuit of treatment effects.

\section{Objectives}

To study plasma volume (PV) and transcapillary escape rate of albumin (TER) in relation to acute inflammation and surgical stress.

\section{Methods}

Healthy volunteers (group A; $\mathrm{n}=10$ ), patients with acute abdominal inflammation and plasma C-reactive protein > $100 \mathrm{mg} / \mathrm{L}$ (group B; $\mathrm{n}=10$ ), and surgical patients during the reconstructive phase of pancreatic resection (group C; $\mathrm{n}=10$ ) were investigated. PV and TER were measured by ${ }^{125}$ I-labeled human serum albumin $\left({ }^{125} \mathrm{I}\right.$-HSA $)$. Groups were compared by one-way analysis of variance.

\section{Results}

Thirty subjects $57 \pm 9$ years were recruited. TER was 4.5 $\pm 1.3,6.1 \pm 1.5$ and $9.6 \pm 5.2 \%$ per hour in groups $\mathrm{A}-\mathrm{C}$, respectively, $(\mathrm{p}=0.006)$. Mean PV was $111 \pm 19,114 \pm$ 15 , and $102 \pm 18 \%(\mathrm{p}=0.79)$ of the corresponding anthropometric values [2]. Plasma albumin was $39.3 \pm$ 2.9, $24.7 \pm 4.9$ and $19.1 \pm 5.3 \mathrm{~g} / \mathrm{L}$ at the start of TER measurement $(\mathrm{p}<0.001)$.

\section{Conclusions}

Capillary leakage assessed by TER was doubled during the later stages of pancreatic resection surgery, compared to the other two groups. While PV was preserved in all 3 groups, plasma albumin was much lower in inflammation and surgery.

${ }^{1}$ Karolinska University Hospital Huddinge, Anaesthesia and Intensive Care, Stockholm, Sweden

Full list of author information is available at the end of the article

\section{Grant Acknowledgment}

Swedish Medical Research Council, and the Country Council of Stockholm

\begin{abstract}
Authors' details
${ }^{1}$ Karolinska University Hospital Huddinge, Anaesthesia and Intensive Care, Stockholm, Sweden. ${ }^{2}$ Karolinska University Hospital Huddinge, Nuclear Medicine, Stockholm, Sweden. ${ }^{3}$ Karolinska Institutet, CLINTEC, Anaesthesia, Stockholm, Sweden.
\end{abstract}

Published: 1 October 2015

\section{References}

1. Chawla LS, Ince C, Chappell D, Gan TJ, Kellum JA, Mythen M, Shaw AD: Workgroup AXF: Vascular content, tone, integrity, and haemodynamics for guiding fluid therapy: a conceptual approach. Br J Anaesth 2014, 113:748-55.

2. Nadler SB, Hidalgo $\mathrm{JH}$, Bloch T: Prediction of blood volume in normal human adults. Surgery 1962, 51:224-32.

doi:10.1186/2197-425X-3-S1-A286

Cite this article as: Komáromi et al:: Capillary leakage with inflammation and surgery. Intensive Care Medicine Experimental 2015 3(Suppl 1):A286.

Submit your manuscript to a SpringerOpen ${ }^{\odot}$ journal and benefit from:

- Convenient online submission

- Rigorous peer review

- Immediate publication on acceptance

- Open access: articles freely available online

- High visibility within the field

- Retaining the copyright to your article

Submit your next manuscript at $>$ springeropen.com

\section{SpringerOpen $^{\circ}$}

C 2015 Norberg et al.; This is an Open Access article distributed under the terms of the Creative Commons Attribution License (http:// creativecommons.org/licenses/by/4.0), which permits unrestricted use, distribution, and reproduction in any medium, provided the original work is properly cited. 